\title{
Development and evaluation of double bullock and single bullock drawn improved steel cart
}

M. Veerangouda, K. V. Prakash, Jag Jiwan Ram and M. Din

Received : 22.12.2017; Revised : 04.02.2018; Accepted : 13.02 .2018

See end of the Paper for authors' affiliation

Correspondence to :

M. Veerangouda Department of Farm Machinery and Power Engineering, College of Agricultural Engineering (U.A.S.), Raichur (Karnataka) India Email : m.veerangouda@ rediffmail.com
- ABSTRACT : In Karnataka, bullock drawn wooden carts are generally used for transportation of agricultural produce and other goods in areas. An improved steel cart suitable for operating with bullock and single bullock power have been developed and fabricated at College of Agricultural Engineering, Raichur. The steel cart power by double bullock and single bullock were tested both on asphalted road and murrum road for carrying the goods. The physiological response of bullocks were noted and analyzed. The wooden material is completely replaced by mild steel and the wheels were provided with protruded rubber to make good contact with road surface. The road surface was not damaged and problem of puncturing the wheel was avoided. The double bullock $(515 \mathrm{~kg}$ body weight) steel cart fitted with bush bearing is capable to carry a load of 8 to 9 quintals safely. The single bullock steel cart fitted with bush bearing is capable to carry a load of 6 quintals safely. The performance of the steel carts drawn by bullock power was satisfactory.

- KEY WORDS : Bullock drawn steel cart, Draft, Hauling, Loading capacity, Road surface

- HOW TO CITE THIS PAPER : Veerangouda, M., Prakash, K.V., Ram, Jag Jiwan and Din, M. (2018). Development and evaluation of double bullock and single bullock drawn improved steel cart. Internat. J. Agric. Engg., 11(1) : 30-34, DOI: 10.15740/HAS/IJAE/11.1/30-34. 